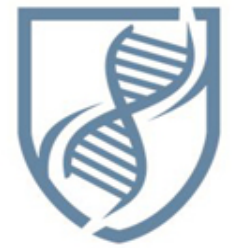

Journal of Bioscience and Applied Research

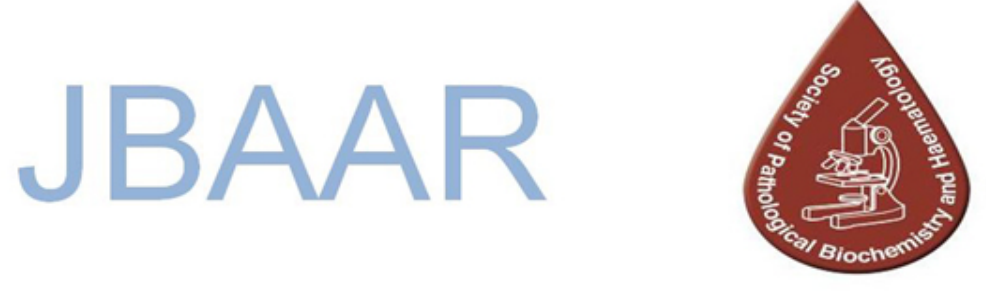

WWW.JBAAR.ORG

\title{
Biological and histopathological effects of cyromazine on the laevae of Culex pipiens (Diptera: Culicidae)
}

\author{
Abada A. Assar ${ }^{1}$, Magda M. Abo El-Mahasen ${ }^{1}$, Amira F.Afifi ${ }^{2}$ and Amany A. Rady ${ }^{2}$ \\ ${ }^{1}$ Zoology Department, Faculty of Science, Menoufia University. \\ ${ }^{2}$ Parasitology Department, Faculty of Medicine, Menoufia University
}

\begin{abstract}
Laboratory studies were carried out to investigate the efficacy of the chitin synthesis inhibitor (cyromazine) against all larval stages of Culex pipiens. The compound was tested its efficacy on larval mortality, larval duration, pupation, pupal duration and adult emergence. Also, the histological effects of cyromazine on the midgut, the integument, the fatbodies and the muscles of $4^{\text {th }}$ larval instar treated as $1^{\text {st }}$ larval instar were studied. The tested compound increased the larval mortality, decreased the percent pupation and adult emergence and prolonged the pupal duration. Also, this compound elicited histological effects on the midgut, the integument, the fat bodies and the muscles of $4^{\text {th }}$ larval instar of $C$. pipiens treated as $1^{\text {st }}$ larval instar with 0.01 and $0.1 \mathrm{ppm}$.
\end{abstract}

Keywords: Culex pipiens, Cyromazine, Histology, Biology

\section{Introduction}

Mosquitoes are vectors of serious human diseases all over the world. Mosquito-borne pathogens infect more than 600 million people annually (Kolberg, 1994). C. pipiens considered as the main vectors of human diseases such as the Rift Valley fever virus (Darwish and Hoogstraal, 1981), viral encephalitis and bird malaria (Kettle, 1995); elephantiasis (Gad et al., 1996), and Western Nile virus (Pelah et al., 2002).

The insect growth regulators (IGRs) have been used in a variety of practical applications and were described as agent that elicit their primary action on insect metabolism, ultimately interfering and disrupting the process of growth, development and metamorphosis of the target insects, particularly when applied during the sensitive period of insect development (Ishaaya and Horowitz, 1997).

Chitin synthesis inhibitors (CSI's) are benzoylphenylurea compounds that interfere with insect development, disturbing the moult and resulting in deformations in the cuticle (Reynolds, 1987). These alterations occur due to CSI's interference in chitin synthesis diminishing the amount of polymer in the insect cuticle (Ishaaya and Casida, 1974; Post et al., 1974). Additionally, adults deriving from CSI's exposed larvae can exhibit a series of physiological constrains that ultimately lead to diminished physical and reproduction fitness (Mondal and Parween, 2000). These CSI's effects vary according to the species, the developmental stage, the time of application, the kind of compound and the administrated dose (Vasuki and Rajavel, 1992, Wilson and Cryan 1997, Mulla et al. 2003). Although several reports in the literature explore the direct effects of CSI's, such as mortality or adult emergence inhibition (Rehimi and Soltani, 1999; Su et al., 2003 and Batra et al., 2005), the consequence of IGR's use on the surviving adults and their implications in vector fitness are less considered, especially among Culicidae (Vasuki 1992, 1999; Vasuki and Rajavel, 1992).

Cyromazine a triazine derivative is an insect growth regulator that is used in veterinary medicine for the protection of animals against insects. This application concerns the external use of cyromazine for the prevention of blow fly strike (Lucilia sericata) on sheep and lamps. Cyromazine is an insecticide that interferes with the first dipteran larval moult and possibly with metamorphosis. Larvae and pupae undergo typical morphological transformations before they die (Emea, 2001).

Insecticide resistance is a growing problem that hampers mosquito control in different regions around the world. Nowadays, resistance to the main neurotoxic insecticide classes has spread among several populations of insect disease vectors. Therefore, biological control methods and the use of chemicals with distinct mechanisms of action have been increasingly employed. The utilization 
of chitin synthesis inhibitors, as cyromazine represents one major current strategy for mosquito chemical control. For this reason, evaluation of the efficacy of such compounds on mosquito field populations is essential (Belianto et al., 2013).Cyromazine has been used since 1984 as a feedthrough although no study has been carried out to assesss the biological and histological effects of cyromazine on $C$. pipiens. The present study was carried out to evaluate the impacts of cyromazine on the biological aspects such as (the larval mortality, larval duration, pupation, pupal duration and adult emergence) and the histological effects on (the integument, midgut, the fat bodies and the muscles) of $C$. pipiens larvae.

\section{Materials and Methods}

A- Insect culture and bioassays:-

The mosquito, $C$. pipiens used in the present study was obtained from susceptible reared strain of Research Institute of Medical Entomology, Doki, Egypt. The colony was maintained under laboratory conditions of $27 \pm 2^{\circ}$ and $75 \pm 5 \%$ R.H. according to El-Bokl and Moawad (1996). The newly $1^{\text {st }}, 2^{\text {nd }}, 3^{\text {rd }}$ and $4^{\text {th }}$ instar larvae were collected for bioassay tests. Different concentrations of cyromazine (0.001, 0.01, 0.1, 1 and $10 \mathrm{ppm})$ were prepared by dissolving the cyromazine powder in water. In each test, 25 larvae were put in a plastic cup with $100 \mathrm{ml}$ tap water and then treated with cyromazine. Control experiments were performed using water only. Each test was replicated four times. A mixture of ground dried bread and Brewer's yeast pellets (3:1) were added daily as food for the larvae. Dead larvae were daily removed and recorded until pupation. The larval mortality was corrected according to Abbott's formula (1987). Larvae, which survived were followed up daily to estimate larval duration. The resultant pupae were counted to determine the percent pupation, followed up till adult emergence to estimate pupal duration and percent of adult emergence.

To study the histopathological effects of cyromazine, some untreated (control) and treated $4^{\text {th }}$ larval instar treated as $1^{\text {st }}$ larval instar with 0.01 and $0.1 \mathrm{ppm}$ of cyromazine were bissected and fixed in Sinha fixative. After fixation all samples dehaydrated, cleared and embedded in paraffin. Embedded samples were sectioned by rotary microtome at $5 \mu \mathrm{m}$ thick. Sections were spread on a clean slide and then left in oven at $37^{\circ} \mathrm{C}$ (overnight). Dired sections were stained with haematoxylin and eosin and then mounted in DPX. Microscopic examination was carried out with research microscope.

\section{B- The compound used:-}

IGR, cyromazine (Trigard) is (Ncyclopropyl1,3,5-triazine-2,4,6-triamine) was obtained from the Ministry of Agriculture.

\section{C-Data Analysis:-}

Data were classified into quantitative and qualitative type. Qualitative data were expressed as mean \pm S.D, while qualitative data were expressed as number and percent. Tests of significance used were: ANOVA "Analysis of variance" to measure the difference between means of more than two groups. Chi square test was applied to assess the difference between qualitative data using SPSS Version (11); statistical package for Social Sciences for Windows XP.

\section{Results}

Treatment of the $1^{\text {st }}, 2^{\text {nd }}, 3^{\text {rd }}$ and $4^{\text {th }}$ larval instars of C. pipiens with different concentrations of cyromazine showed highly significant increase in larval mortality with increasing the concentration of cyromazine. Also, there was significant difference in the larval mortality for all instars on treatment with the same concentration of cyromazine except at $0.01 \mathrm{ppm}$ (Table 1a).

The corrected percentages of larval mortality (Table 1b) had a positive relationship with different concentration of cyromazine. The corrected larval mortality percent reached $100 \%$ on the 1 st and 2 nd larval instars at $10 \mathrm{ppm}$, while decreased with the 3rd and 4th larval instars (95.87 and 93.81\%, respectively).

There was no statistically significant differences between tested concentrations of cyromazine on larval duration of different treated larval instars in comparing with control group (Table 2).

The percentage of pupation resulted from larvae treated as $1^{\text {st }}, 2^{\text {nd }}, 3^{\text {rd }}$, and $4^{\text {th }}$ instar of $C$. pipiens with cyromazine was highly reduced in comparison to the control (table 3). Also, there was significant difference between the treated larvae regarding percent pupal at the highest concentration of cyromazine only ( 1 and $10 \mathrm{ppm})$. No pupae were detected with $1^{\text {st }}$ instar larvae treated with 1 and $10 \mathrm{ppm}$ and with $2^{\text {nd }}$ instar larvae treated with $10 \mathrm{ppm}$ of cyromazine.

The data obtained (Table 4) show that CSI, cyromazine used resulted in increasing the mean pupal duration of $C$. pipiens pretreated as $1^{\text {st }}, 2^{\text {nd }}, 3^{\text {rd }}$ and $4^{\text {th }}$ instar larvae as compared to control. This effect was dose dependent on all the larval instars. Also, there was significant difference in the mean of pupal duration of all larval instars treated with the same concentration.

The percentage of adult emergence was significantly decreases with increasing the concentration of cyromazine for all treated larval instars compared with control group. Also, there was significant difference regarding percentage of adult emergence between treated larvae with different concentrations of cyromazine except with the high cocncentration of $10 \mathrm{ppm}$. No adult emergence was detected with instar larvae treated with 1 and $10 \mathrm{ppm}$ and with $2^{\text {nd }}$ instar larvae treated with $10 \mathrm{ppm}$ of cyromazine (Table 5).

Histological effects of cyromazine on the $4^{\text {th }}$ larval instar of $C$. pipiens treated as $\mathbf{1}^{\text {st }}$ larval instar:-

Normal structure of the integument as shown in Fig.(1) consists of three layers: inner basement membrane, a single layer of epidermal (hypodermal) cells and outer cuticle which is subdivided into inner endocuticle, middle exocuticle and outer epicuticle.

Treatment the larvae of $C$. pipiens with $0.01 \mathrm{ppm}$ of cyromazine induced separation of the cuticle from the hypodermis with partial degeneration and vaculation of 
hypodermal cells as shown in Fig. (2 and 3). Complete degeneration of hypodermis and the cuticle became very thin with treatment of the larvae of $C$. pipiens with $0.1 \mathrm{ppm}$ of cyromazine.

Normal structure of the midgut is shown in Fig(5) with a single layer of columanar epithelial cells, each containing a nucleus with striated (brush) border.

Treatment the larvae with $0.01 \mathrm{ppm}$ of cyromazine induced slight degeneration in the epithelial cells with little vaculation were observed Fig. (6), while treatment the larvae with $0.1 \mathrm{ppm}$ of cyromazine (Fig.7) showed more degeneration, vaculation and absence of cell boundaries between the epithelial cells.

Normally, the fat cells has rounded or polyhedral shape with a nucleus and vaculations. It is found throughout the haemocoele and usually concentrated around internal organ. It is important for synthesis and storage of the reverse materials and also has excretory functions (Fig.8). The effect of cyromazine on the fat cells showed degeneration of most of the fat cells with the separation fat cells from each other ( Fig. 9 and 10). The effect was dose dependent.

The normal histological muscles (Fig.11) is composed of a number of long fibres. Each of these in turn are subdivided into separate, smaller fibrils which are themselves composed of a highly organized array of myofilaments made up of the proteins actin and myosin. The fibre is surrounded by an outer membrane, the sarcolemma, which encloses the nucleated sarcolemma in which the fibrils are embedded. Each fibril is typically composed of alternating isotropic and anisotropic.

Treatment C. pipiens larvae with $0.01 \mathrm{ppm}$ of cyromazine induced separation and degeneration of muscle fibres (Fig.12), which increased with 0.1 ppm. (Fig.13)

\section{Discussion}

The treatment of CSI, cyromazine has successive effects on all four larval instars of $C$. pipiens. The effects depend on the concentration or dose of the compound and the age of the treated larvae.

Jemaez and Boushih (2010) when they treated $2^{\text {nd }}$ instar larvae of Ceratitis capitata with $0.05 \mathrm{M} / \mathrm{L}$ conc of cyromazine, the larval mortality was $91 \%$.

Besides, Kayser and Palivan (2006) when they feed larvae of dipteran species (Musca domestica, Lucilia sericata, Calliphora vicina and Protophormia terraenovae) diet added with cyromazine $(0.25 \mathrm{mg} / \mathrm{L})$, there was an important insecticidal effect. Also, the current results were in a harmony with Mulla et al. (1989) who found that hexaflumuron at $0.92 \mathrm{ppm}$ induced $90 \%$ mortality in $C$. quinquesfasciants larva (C. pipiens molestus). Rather than Vauski and Rajavel (1992) who reported that hexaflumuron was toxic to $C$. quinquesfasciants larva at 0.01 and 0.1 $\mathrm{mg} / \mathrm{L}$. Also, they revealed that larval mortality increased with increasing the time and concentration of exposure to growth regulator.

Hlofenozide at $25.58 \mu \mathrm{g} / \mathrm{L}$ and pyriproxyfen at 0.01 $\mathrm{mg} / \mathrm{L}$ induced $90 \%$ mortality of $4^{\text {th }}$ instar larvae of $C$. pipiens and $100 \%$ mortality in Aedes aegypti larva, respectively (Boudjelida et al., 2002 and Vythilingam et al., 2005).

Several authors have observed that high doses of CSI's cause more pronounced mortality of mosquito larvae, relative to pupae and adults (Reynolds, 1987; Mulla et al., 2003 and Su et al., 2003).

Also the obtained results agree with the findings of El-Gammal et al. (1993) using chlorfluazuron on Schistocerca gregaria. On the other hand (Farag, 1979) reported that dimilin caused slight larval mortalities to the larvae of Spodoptera littoralis.

According to the results of this work, there was no significant difference in the larval duration was detected. On the other harnd, Al-Mekhalafi et al. (2011) revealed that cyromazine increased the larval duration of Cowpea Weevil, Callosobruchus maculatus where the average duration reached 27, 28.75, 28.92 days at $1,3,5 \%$, respectively. Also, housefly larvae reared on food treated with subleathal conc. of cyromazine led to increase of the average of larval duration stages (11.20 days) compared with 6.5 days for control (Al-Abadi, 2001).

Many studies evaluated the effects of the other CSI's agents where Abo El-Mahasen (2010) treated the 1st larval instar of $M$. domestica with "Lufenuron" a CSI's resulted in a significant prolongation in the larval durations where it was 5.27, 5.85, 6.37 and 7.99 days at 10, 100, 1000, 2000 ppm, respectively. With the highest novaluron condition, EI99, L4 larvae of $A$. aegypti ecdysis began on the $3^{\text {rd }}$ day and finished between days 4 and 5 . However, only $60 \%$ of the larvae succeeded in completing the entire molting process, reaching L4. Only $2.5 \%$ of the specimens reached the pupal stage and no immature became adult (Farnesi et al., 2012).

This study reported that there was highly significant difference in the mean of pupal duration of all treated larvae. It was dose dependent.

This effect of cyromazine on pupae coincided with the effect reported by (Al-Mekhalafi et al., 2011) when they found in all cyromazine conc. used. There was increasing in the average duration of pupal stage of $C$. maculatus where it reached 9.08, 9.67, 10.08 days for 1,3 , $5 \%$ conc. compared with 8.75 days for control.

Also, Farnesi et al. (2012) reported that Novaluron $\mathrm{EI}_{50}(0.14 \mu \mathrm{g} / \mathrm{L})$ used for $3^{\text {rd }}$ instar larvae of $A$. aegypti. The pupation period prolonged until $14^{\text {th }}$ day.

On the other hand, the $\mathrm{LC}_{50}$ of pyriproxyfen led to decrease of the length of pupal period from 1.99 days in control group to 1.83 days in treated group which was similar to halofenozide at $8.32 \mathrm{mg} / \mathrm{L}$ which led to reduction of mean pupal duration of fourth instar larvae of $C$. pipiens (Boudjelida et al., 2002).

The results of this study revealed that there was decrease of the percent pupation. These results coincided with Al-Mekhalafi et al. (2011) where they reported that increasing concentration of cyromazine led to significantly reduction in the success rate of pupation of $C$. maculatus 
Table (1a): Effect of cyromazine on the larval mortality of Culex pipiens.

\begin{tabular}{|c|c|c|c|c|c|c|}
\hline \multirow[t]{2}{*}{ Conc. (ppm.) } & \multicolumn{4}{|c|}{ Larval mortality \% } & \multirow[t]{2}{*}{ Chi-square } & \multirow[t]{2}{*}{ P. value } \\
\hline & $1^{\mathrm{st}}$ & $2^{\text {nd }}$ & $3^{\text {rd }}$ & $4^{\text {th }}$ & & \\
\hline 0.0 & 5 & 4 & 3 & 3 & 0.76 & $>0.05^{\mathrm{NS}}$ \\
\hline 0.001 & 42 & 37 & 29 & 25 & 7.96 & $<0.05^{*}$ \\
\hline 0.01 & 54 & 48 & 42 & 36 & 7.27 & $>0.05^{\mathrm{NS}}$ \\
\hline 0.1 & 75 & 72 & 58 & 49 & 19.2 & $<0.01^{*}$ \\
\hline 1 & 100 & 95 & 89 & 82 & 23.27 & $<0.01^{*}$ \\
\hline 10 & 100 & 100 & 96 & 94 & 11.08 & $<0.05^{*}$ \\
\hline Chi-square test & 289.26 & 280.79 & 255.49 & 239.16 & & \\
\hline P. value & $<0.01^{* *}$ & $<0.01^{* *}$ & $<0.01^{* *}$ & $<0.01^{* *}$ & & \\
\hline
\end{tabular}

$1^{\text {st }}$ : First larval instar

$3^{\text {rd }}$ : Third larval instar

$2^{\text {nd }}:$ Second larval instar

$4^{\text {th }}:$ Fourth larval instar

NS: non significant $\quad$ *: significant $\quad * *$ : highly significant

Table (1b): The corrected larval mortality* of Culex pipiens

\begin{tabular}{|c|c|c|c|c|}
\hline \multirow{2}{*}{ Conc. (ppm.) } & \multicolumn{4}{|c|}{ Corrected larval mortality \% } \\
\cline { 2 - 5 } & $1^{\text {st }}$ & $2^{\text {nd }}$ & $3^{\text {rd }}$ & $4^{\text {th }}$ \\
\hline 0.001 & 38.94 & 34.37 & 26.80 & 22.68 \\
\hline 0.01 & 51.57 & 45.83 & 40.20 & 34.02 \\
\hline 0.1 & 73.86 & 70.83 & 56.70 & 47.42 \\
\hline 1 & 100 & 94.79 & 88.65 & 81.44 \\
\hline 10 & 100 & 100 & 95.87 & 93.81 \\
\hline
\end{tabular}

${ }^{(*)}$ Corrected larval mortality according to Abbott's Formula (1987) $=\mathrm{X}-\mathrm{Y} / \mathrm{X}$

$\mathrm{X}=\%$ of living control larvae $\quad \mathrm{Y}=\%$ of living treated larvae 
Table (2): Effect of cyromazine on the larval duration of Culex pipiens

\begin{tabular}{|c|c|c|c|c|}
\hline \multirow{2}{*}{ Conc. (ppm.) } & \multicolumn{4}{|c|}{ Larval duration (Mean \pm SD) days } \\
\cline { 2 - 5 } & $1^{\text {st }}$ & $2^{\text {nd }}$ & $3^{\text {rd }}$ & $4^{\text {th }}$ \\
\hline 0.0 & $13.29 \pm 2.71$ & $11.57 \pm 0.89$ & $9.08 \pm 1.61$ & $6.41 \pm 1.35$ \\
\hline 0.001 & $13.83 \pm 1.57$ & $11.76 \pm 1.67$ & $9.32 \pm 1.65$ & $6.66 \pm 1.63$ \\
\hline 0.01 & $13.60 \pm 1.93$ & $11.88 \pm 2.96$ & $8.96 \pm 1.91$ & $6.55 \pm 0.91$ \\
\hline 0.1 & $13.48 \pm 2.54$ & $11.77 \pm 1.11$ & $8.95 \pm 2.29$ & $6.44 \pm 1.94$ \\
\hline 1 & - & $11.85 \pm 1.3$ & $8.90 \pm 1.45$ & $6.63 \pm 1.64$ \\
\hline 10 & - & - & $8.66 \pm 0.58$ & $6.75 \pm 1.40$ \\
\hline Chi-square test & 1.02 & 0.49 & 1.69 & 0.26 \\
\hline P. value & $>0.05^{\text {NS }}$ & $>0.05^{\text {NS }}$ & $>0.05^{\text {NS }}$ & $>0.05^{\text {NS }}$ \\
\hline
\end{tabular}

NS: non significant

Table (3): Effect of cyromazine on the percent pupation of Culex pipiens

\begin{tabular}{|c|c|c|c|c|c|c|}
\hline \multirow[t]{2}{*}{ Conc. (ppm.) } & \multicolumn{4}{|c|}{ \% pupation } & \multirow{2}{*}{$\begin{array}{l}\text { Chi- } \\
\text { square } \\
\text { test }\end{array}$} & \multirow[t]{2}{*}{ P. value } \\
\hline & $1^{\mathrm{st}}$ & $2^{\text {nd }}$ & $3^{\text {rd }}$ & $4^{\text {th }}$ & & \\
\hline 0.0 & 95 & 96 & 97 & 97 & & \\
\hline 0.001 & 58 & 63 & 71 & 75 & 0.72 & $>0.05^{\mathrm{NS}}$ \\
\hline 0.01 & 46 & 52 & 58 & 64 & 1.92 & $>0.05^{\mathrm{NS}}$ \\
\hline 0.1 & 25 & 28 & 42 & 51 & 1.69 & $>0.05^{\mathrm{NS}}$ \\
\hline 1 & 0.0 & 5 & 11 & 18 & 2.55 & $<0.05^{*}$ \\
\hline 10 & 0.0 & 0.0 & 4 & 6 & 3.41 & $<0.05^{*}$ \\
\hline $\begin{array}{l}\text { Chi-square } \\
\text { test }\end{array}$ & 289.26 & 280.79 & 255.49 & 239.16 & & \\
\hline P. value & $<0.01^{* *}$ & $<0.01^{* *}$ & $<0.01^{* *}$ & $<0.01^{* *}$ & & \\
\hline
\end{tabular}


Table (4): Effect of cyromazine on the pupal duration of Culex pipiens.

\begin{tabular}{|c|c|c|c|c|c|c|}
\hline \multirow{2}{*}{$\begin{array}{c}\text { Conc. } \\
\text { ppm. }\end{array}$} & \multicolumn{4}{|c|}{ Pupal duration (Mean \pm SD) days } & \multirow{2}{*}{$\begin{array}{c}\text { ANOVA } \\
\text { test }\end{array}$} & $\begin{array}{c}\text { P. } \\
\text { value }\end{array}$ \\
\cline { 2 - 6 } & $1^{\text {st }}$ & $2^{\text {nd }}$ & $3^{\text {rd }}$ & $4^{\text {th }}$ & & \\
\hline 0.0 & $5.23 \pm 1.28$ & $5.73 \pm 1.95$ & $5.85 \pm 1.4$ & $5.90 \pm 1.4$ & 36.95 & $>0.05$ \\
\hline 0.001 & $8.05 \pm 2.02$ & $6.38 \pm 2.48$ & $6.91 \pm 1.95$ & $7.68 \pm 1.45$ & 8.9 & $<0.05$ \\
\hline 0.01 & $9.94 \pm 0.86$ & $8.00 \pm 1.32$ & $7.64 \pm 1.43$ & $8.81 \pm 2.15$ & 17.04 & $<0.05$ \\
\hline 0.1 & $12.41 \pm 1.18$ & $9.57 \pm 0.51$ & $9.02 \pm 2.57$ & $10.23 \pm 0.44$ & 15.65 & $<0.05$ \\
\hline 1 & - & $10.2 \pm 0.6$ & $9.6 \pm 1.7$ & $10.9 \pm 1.1$ & 14.32 & $>0.05$ \\
\hline 10 & - & - & $10.03 \pm 1.2$ & $11.3 \pm 0.9$ & 16.13 & $<0.005$ \\
\hline $\begin{array}{c}\text { ANOVA } \\
\text { test }\end{array}$ & 468.62 & 99.22 & 49.19 & 150.85 & & \\
\hline P. value & $<0.01^{* *}$ & $<0.01^{* *}$ & $<0.01^{* *}$ & $<0.01^{* *}$ & & \\
\hline
\end{tabular}

NS: non significant $\quad *$ : significant $\quad * *$ : highly significant

Table (5): Effect of cyromazine on the percent adult emergence of Culex pipiens

\begin{tabular}{|c|c|c|c|c|c|c|}
\hline \multirow[b]{2}{*}{ Conc. (ppm.) } & \multicolumn{4}{|c|}{ \% adult emergence } & \multirow{2}{*}{$\begin{array}{l}\text { Chi- } \\
\text { square } \\
\text { test }\end{array}$} & \multirow[t]{2}{*}{ P. value } \\
\hline & $1^{\text {st }}$ & $2^{\text {nd }}$ & $3^{\text {rd }}$ & $4^{\text {th }}$ & & \\
\hline 0.0 & 92 & 93 & 94 & 94 & 0.55 & $>0.05^{\mathrm{NS}}$ \\
\hline 0.001 & 54 & 59 & 68 & 71 & 2.03 & $<0.05^{*}$ \\
\hline 0.01 & 35 & 46 & 51 & 58 & 2.29 & $<0.05^{*}$ \\
\hline 0.1 & 18 & 22 & 37 & 59 & 3.01 & $<0.01^{*}$ \\
\hline 1 & 0.0 & 3 & 7 & 12 & 3.57 & $<0.01^{*}$ \\
\hline 10 & 0.0 & 0.0 & 2 & 3 & 1.75 & $>0.05^{\mathrm{NS}}$ \\
\hline Chi-square test & 381.44 & 276.23 & 256.91 & 243.13 & & \\
\hline P. value & $<0.01^{* *}$ & $<0.01^{* *}$ & $<0.01^{* *}$ & $<0.01^{* *}$ & & \\
\hline
\end{tabular}




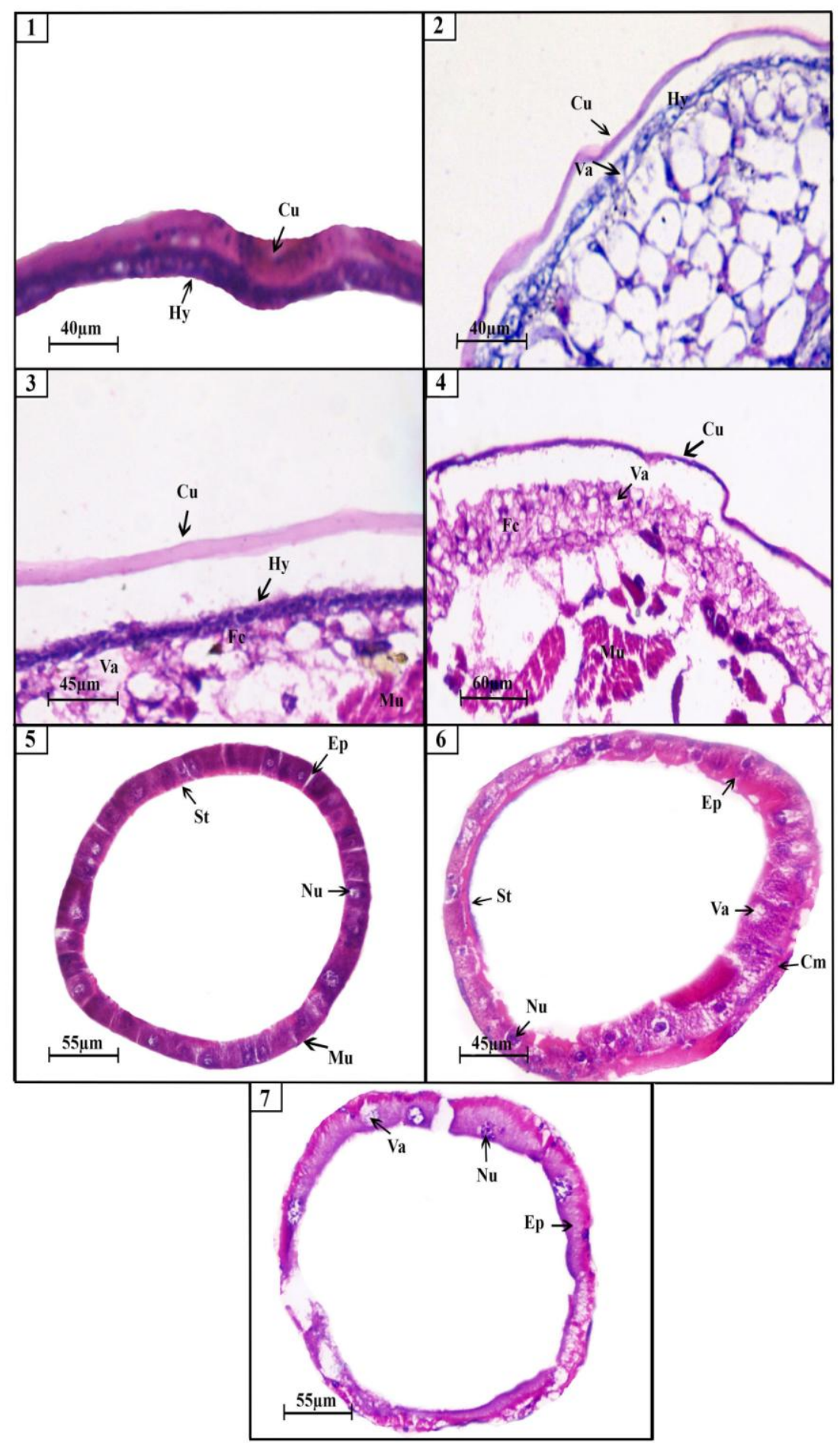

Fig. (1): V.S in the body wall (integument) of untreated $4^{\text {th }}$ larval instar of C. pipiens.

Fig. (2): V.S in the body wall of $4^{\text {th }}$ larval instar of C. pipiens treated as $1^{\text {st }}$ larval instar with 0.01 ppm of cyromazine. Fig. (3-4): V.S in the body wall of $4^{\text {th }}$ larval instar of $C$. pipiens treated as $1^{\text {st }}$ larval instar with 0.1 ppm of cyromazine. Fig. (5): T.S. in the midgut of untreated $4^{\text {th }}$ larval instar of $C$. pipiens.

Fig. (6): T.S. in the midgut of $4^{\text {th }}$ larval instar of C. pipiens treated as $1^{\text {st }}$ larval instar with 0.01 ppm of cyromazine. Fig. (7): T.S. in the midgut of $4^{\text {th }}$ larval instar of C. pipiens treated as $1^{\text {st }}$ larval instar with 0.1 ppm of cyromazine. 

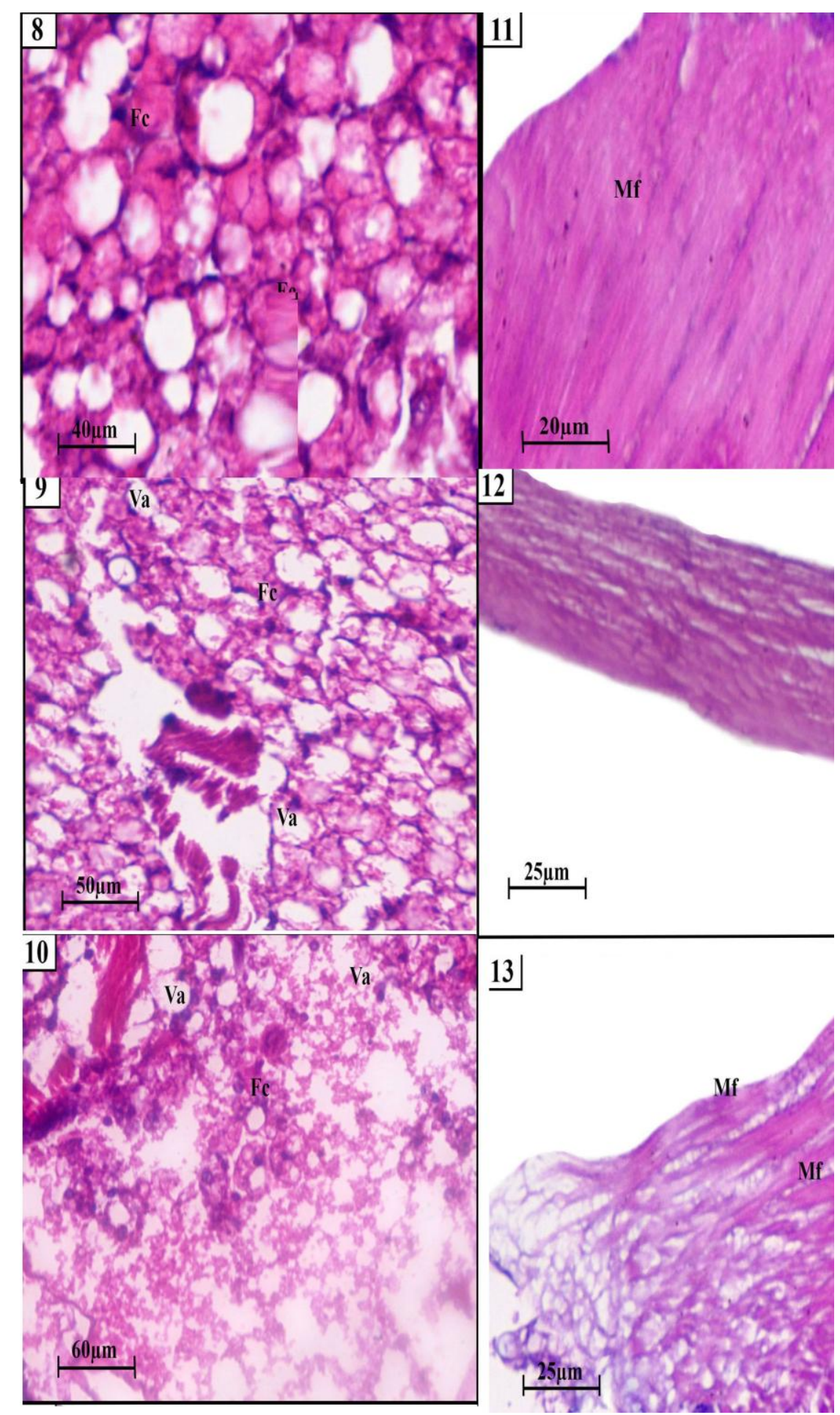

13

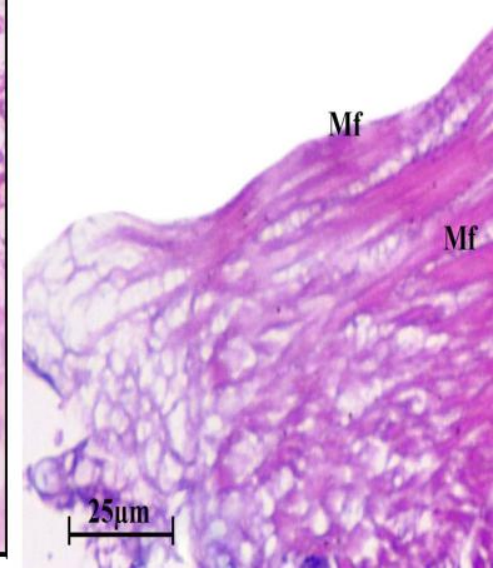

Fig. (8): Section in the fat bodies of untreated $4^{\text {th }}$ larval instar of C. pipiens.

Fig. (9): Section in the fat bodies of $4^{\text {th }}$ larval instar of $C$. pipiens treated as $1^{\text {st }}$ larval instar with $0.01 \mathrm{ppm}$ of cyromazine. Fig. (10): Section in the fat bodies of $4^{\text {th }}$ larval instar of $C$. pipiens treated as $1^{\text {st }}$ larval instar with $0.1 \mathrm{ppm}$ of cyromazine. Fig. (11): Section in the muscles of untreated $4^{\text {th }}$ larval instar of $C$. pipiens.

Fig. (12): Section in the muscles of $4^{\text {th }}$ larval instar of C. pipiens treated as $1^{\text {st }}$ larval instar with $0.01 \mathrm{ppm}$ of cyromazine. Fig. (13): Section in the muscles of $4^{\text {th }}$ larval instar of $C$. pipiens treated as $1^{\text {st }}$ larval instar with $0.1 \mathrm{ppm}$ of cyromazine. 
when exposed to $1,3,5 \%$ concentration of cyromazine, the percentage of reduction reached 50.67, 33.75 and 19.83\%, respectively in comparing with $87.33 \%$ for control. Also, when the $1^{\text {st }}$ larval instar of $A$. aegypti exposed to novaluron $\mathrm{EI}_{99}(0.3 \mu \mathrm{g} / \mathrm{L})$, only $2.5 \%$ on the specimens reached the pupal stage (Farensi et al., 2012).

Hexaflumuron also reduced percent pupation of $C$. quinquesfasciants, A. aegypti and A. stephensi (Amalraj and Das, 1996 and Rajasekan and Jebansan, 2012) studied the efficacy of novaluron against Culex spp. In field condition at two doses at 0.05 and $0.5 \mathrm{mg} / \mathrm{L}$, they reported that pupal reduction was $86 \%$ and $100 \%$, respectively. Indrains cyromazine was effective in inhibiting and reducing adult emergence of $C$. pipiens at $10 \mathrm{ppm}$. conc. where it was $100 \%, 100 \%, 98 \%, 97 \%$ in all stages respectively. Mulla et al. (1989) recorded 85 and 100\% inhibition of adult emergence of $C$. tarsalis at 0.01 and $0.025 \mathrm{Ib}$ a.i./acre, respectively.

Also, there was clear and significant reduction in the average rate of adult emergence of $C$. quinquesfasciants where it was 53.5, 35.7 and $27.08 \%$ for $1,3,5 \%$ concentration of cyromazine in comparison with $86.5 \%$ for control (Al-Mekhalafi et al., 2011). Vasuki (1992) found that hexaflumuron reduced adult emergence of $A$. aegypti and it was dose-dependant. Also, Vasuki and Rajavel (1992) reported $100 \%$ inhibition of adult emergence of $C$. quinquefasciatus was achieved at 0.1 and $0.01 \mathrm{mg} /$ litre of hexaflumuron. Using novaluron as CSI induced 100\% inhibition of adult emergence of second instar larvae of $A$. aegypti at 0.25-1 microgram/litre (Mulla et al., 2003).

Other IGRs proved to be effective in reducing adult emergence of different species of mosquitoes at different concentrations, methods of application, stage treated and also in field and laboratory were, mthoprene and diflubenzuron on C. quinquefasciatus (Moreno and Scorz, 1983), J.270 (1,1 dimethyl 6 phenylethyl phenol) on C. quinquefasciatus and A. aegypti (Nelson et al. 1983), J.2a31 (1,1 dimethylethyl z methoxy 3,4 methoxyphenyl methyl benzene) on third instar larvae of $C$. quinquefasciatus (Soltani et al., 1994) and Novaluron on A. aegypti (Su et al., 2003).

The efficacy of Novaluron against percent inhibition of adult emergence (EI) of Culex spp in field conditions was evaluated at two doses at 0.05 and $0.5 \mathrm{mg} / \mathrm{l}$ in three different breeding habitats. In drains, the density of late instar showed decline from day three at both the test doses. At $0.05 \mathrm{mg} / \mathrm{l}$ the reduction of late instar ranged between $92 \%, 94 \%$ and $98 \%$ up to sixth week and then declined to $69.28 \%$ in seventh week. The pupal reduction was observed in $86 \%$ in sixth week. At the dose of $0.5 \mathrm{mg} / \mathrm{l}$, $100 \%$ pupal reduction remained up to fifth week. In pools, the reduction of late instar ranged from 47.05 to $85 \%$ up to seventh week at both the doses. In tanks the effect of Novaluron was slightly better than pools, where $100 \%$ reduction of late instars was observed after three weeks at $0.05 \mathrm{mg} / \mathrm{l}$ and $0.5 \mathrm{mg} / \mathrm{l}$ (Rajasekan and Jebanesan, 2012).

These results were in a harmony to Reynolds and Blaky (1989) have shown that an early action of cyromazin is to cause the cuticle to become less extensible when subjected to simple constant load extension test.

The decrease in the percentage of adult emergence could be due to the fact that IGRs block the maturation of imaginal discs are the primordia of many adults integumentary structures in endopteryogote insects (Schneidermann, 1972).

The tested CSI induced some histopathological effects on the body wall, the midgut, the fatbodies and the muscles of $4^{\text {th }}$ larval instar of $C$. pipiens treated as $1^{\text {st }}$ larval instar.

Salama et al .(2002) stated that hematoporphyrin at sublethal concentrations caused cytoplasmic vacuoles in the midgut cells of C.pipiens larvae, also caused vacuolizations in the fat body and caused loss of lamellate cuticle, cuticular change into amorphous layer, the endo and exocuticle were indistinguishable and epidermal cells under the cuticle were distorted.

Bennington (2005) reported that hexaflumuron caused decreased cuticle thickness in Lucilia cuprina. Diflubenzuron, chlorofluzuron, triflumuron and buprofezin (all are chitin synthesis inhibitors) caused decrease cuticle thickness and separation of cuticle from hypodermal layer in C. pipiens. On the other hand, Awad and Mulla (1984) mentioned that there was no histological eefect on the midgut cells and on the body wall of $4^{\text {th }}$ instar larvae of $C$. quinquefasciatus when treated with cyromazine.

Finally, it can be concluded that the CSI tested in the present study could suppress the populations of $C$. pipiens either directly through their insecticidal activity against larvae or indirectly through their latent effect against adults which survived larval treatment. This latent effect was expressed in reducing the percentage of adult emergence. The higher activities of cyromazine obtained here may deserve attention and stimulate efforts to use them in controlling or suppressing the population of $C$. pipiens under field conditions.

\section{References}

Abbott, W. (1987): A method of computing the effectiveness of insecticide, J.American Mosq. Cont. Assoc., 3 (20): 302-303.

Abo El-Mahasen, M.M.; Assar, A.A.; Khalil, M.E. and Hussein,S.M. (2010): Biological effects of some insect growth regulators on the house fly, Musca domestica (Diptera: Muscidae): Egypt.Acad.J.Biolog.Sci., 3 (2): 95105 .

Al-Abadi, A.K. (2001): Biological effects of some insecticides on the house fly, Musca domestica (Muscidae: Diptera). Master Thesis, College of Adriculture and Forestry, Mosul University, Mosul, Iraq.

Al-Mekalafi, F.A.; Mashaly, A. M.; Wadaan, M. A. and Al-Mallah, N. M. (2011):Cyromazine concentration and host type effects on the biology of the southern cowpea weevil Callosobruchus maculates F. African J. Microbio. Res., 5 (20):3321-3326.

Amalraj, D. and Das, P.K. (1996): Toxicity of insecticides to Toxorhynchites splendens and three vector 
mosquitoes and their sublethal effect on biocontrol potential of the predator. Southeast Asian J. of Trop. Med. and Public Health., 27 (1): 154-159.

Awad, T. I. and Mulla, M. S. (1984): Morphogenetic and histopathological effects induced by the insect growth regulator cyromazine in Musca domcstica. J. Med. Entomol., 21 (4): 419 - 426.

Batra, C.P., Mittal, P.K., Adak, T. and Ansari, M.A. (2005): Efficacy of IGR compound starycide-480 SC (triflumuron) against mosquito larvae in clear and polluted water. J. Infect Borne Dis., 42:109-116.

Belinato,T.A.; Martins,A.J.; Pereira Lima, J.B. and Valle,D. (2013): Effect of triflumuron, a chitin synthesis inhibitor on Aedes aegypti, Aedes albopictus and Culex quinquefasciatus under laboratory conditions. Parasites and Vectors, 6:83.

Bennington, C. K. (2005): Ultrastructural changes in the cuticle of the sheep blowfly, Lucilia induced by certain insecticides and biological inhibitors. Tissue and cell, 17:131-140.

Boudjelida, H.; Bouaziz, A.; smagghe, G. and Soltani, N. (2002): Insecticidal activity of nonsteroidal moulting hormone agonist on mosquito larvae and effects on ecdysteriod amounts. Meded Rijksuniv Gent Fak Landbouwkd Biol.Wet., 67 (3): 657-663

Darwish, M. and Hoogstraal, H. (1981): Arboviurses infesting human and lower animals in Egypt. Review of the thirty years of research. J. Egypt Public Health Assoc., 56:1-11.

El-Bokl, M.M. and Moawad, H.M. (1996): Evaluation of some plant exracts as mosquito larvicides. Ain Shams Sci, Bull., 34:351-362.

El-Gammal, A. M.; Osman, M. A.; Shaban, O. A. and Badawy, N. S. (1993): The role of the anti-chitin synthesis, chlorfluazuron (IKI) on the main metabolites during metamorphosis of Schistocerca gregaria (Forskal).Egypt. J. Agric. Sci., 71 (4): 891- 899.

El-Sokkary, Z. F. (2003): Biological and physiological effects of some insect growth regulators and botanicals on the desert locust Schistocerca gregaria Forskal. M.Sc. Thesis, Fac. Sci., Ain Shams Univ.

Emea (2001): Committee for veterinary medicinal products cyromazine summary report (2). Emea, The European Agency for the Evaluation of Medicine and inspections. 1-5.

Farag, A.R. (1979): Studies on irradiated control of some cotton insects. " Factors affecting the control of the two major cotton insects by Bacillus thuringiensis and Dimilin. Ph.D. Thesis Alex. Univ. Egypt.

Farensi, L.C.; Brito,J.M.; Linss, J.G.; PelayoMachado, M.; Valle,D. and Rezende, G.L. (2012): Physiological and morphological aspects of Aedes aegypti developing larvae. Effects of the chitin synthesis inhibitor Novaluron. Plos, (7):1-9.

Gad, M.M.; Hammad, R.E. and Farid, H.A. (1996): Uptake and development of Wuchereria bancrofti in Culex pipiens L and Aedes caspius pallas. J. Egypt. Soc. Parasitol., (2): 305-314.

Ishaaya, I. and Casida, I. E. (1974): Dietary TH6040 alters composition and enzyme activity of house fly larval cuticle. Pestic. Biochem. and Physiol., 4: 484-490.

Ishaaya, I. and Horowitz, A. R. (1997): Insecticides with novel mode of actions: Overview. pp. 1-39. In: "Insecticides with novel mode of actions, Mechanisms and application" Eds. By Ishaaya, I. and Degheele, D. ,Berlin.

Jemaez, M. and Boushih, E. (2010): Cyromazine induced effects on larvae and adults of laboratory Tunisian strains of the Mediaterranean fruit fly Ceratitis capitata. Tunisian Journal of Plant Protection 5: 213-222.

Kayser, Hand Palivan, C.G. (2006): Stable free radicals in insect cuticles electron spin resonance spectroscopy reveals differences between melanization and sclerotization .Arch. Bio. Chem. Biophys.,453:179:187

Kettle, D.S. (1995): Internal structure and function of insects (Chap.5). Medical and veterinary Entomology, 2nd Ed. Cap. Int. Uk. 140-167.

Kolberg, R. (1994): Finding sustainable ways to present parasitic diseases. Science, 264: 1816- 1859.

Mondal, K. and Parween, S. (2000): Insect growth regulators and their potential in management of storedproduct insect pests. Int. Pest. Manag. Rev., 5:255-295.

Moreno, G. and Scorz, J.V. (1983): In vitro activity of Altosid and Dimilin against larvae of Culex pipiens, Aedes aegypti and Anopheles nuneztovari from West of Venezuela. Boletin de la Direccion de Malariologia Saneamiento Ambiental, 23(1-4): 1-10.

Mulla, M.S.; Darwazeh, H.A. and Schreiber, E.T. (1989): Impact of new insect growth regulators and their formulations on mosquito larval development in impoundment and foodwater habitats. J. of Anu. Mosq. Control Assoc., 5(1):15-20.

Mulla, M.S.; Thavara, U.; Tawatsin,A.; Chompoosri, J.; Zaim, M. and Su, T.Y. (2003): Laboratory and field evaluation of novaluron, a new acylurea insect growth regulator against Aedes aegypti (Diptera: Culicidae). J. vector Ecol., 28(2): 241-254.

Nelson, F.R.; Rejali, A. and Mohamed, A.K. (1983): Susceptibility of Aedes aegypti and Culex quinquefasciantus to a new insect growth regulator. J Florida Antimosquito Assoc., 54(1): 8-10.

Pelah, D.; Abramovich, Z.; Markus, A. and Wiesman, Z. (2002): The use of commercial Saponin from Quillija saponaria bark as a natural larvicide against Aedes aegypti and Culex pipiens. J. Enthnopharmacol., 81(3): 407- 409.

Post, L.C.; de Young, B.J.; Vincent, W.R. (1974): 1(2,6-disubstituted benzoyl)-3-phenylurea insecticides, inhibitors of chitin synthesis. Pestic Biochem. Physiol., 4:473-483.

Rajasekan,P. and Jebanesan, A. (2012): Efficacy of IGRs compound Novaluron and Buprofezin against Culex quinquefasciatus mosquito larvae and pupal control in pools , drains and tanks. Inter. J. Res. in Biological Sciences. 2 (1):45-47.

Rao,P.A. and Mehrota, K.N. (1988): Toxicity of diflubenzuron to Schistocerca gregaria Forskal. (Bibliographic citation): Indian J. Entomology, 44(4): 474477 . 
Rehimi, N. and Soltani, N. (1999): Laboratory evaluation of Alsystin- a chitin synthesis inhibitor against Culex pipiens L. (Diptera: Culicidae) effects on development and cuticle secretion. J. Appl. Entomol., 123: 24. 437-441.

Reynolds, S.E. (1987): The cuticle, growth and moulting in insects: the essential background to the action of acylurea insecticides. Pest Sci., 20:131-146.

Reynolds, S.E and Blakey, J.K. (1989): Cyromazine causes decreased cuticle extensibility in larvae of the tobacco homworm, Manduca sexta. Pestic Biochem Physto, 35: 251-259.

Salama, E.; El-Sherbini, S.; Abdel-Kader, M. and Jorim G. (2002): Site of action of hematoporphyrin (a photo-activated insecticide) in Culex pipiens larvae. Egypt. J. Biol., 4:133-141.

Schineidermann, H. A. (1972): Insect hormone and insect control. In: insect juvenile hormone, Chemistry and action. Mean, J. Beroza, M. (Eds). Academic presses. New York. London: 3-27.

Soltani, N.; Rehimi, N.; Beldi, H. and Bendali, F. (1994): Activity of triflumuron on Culex pipiens (Diptera: Culicidae) and impacts on two larvivorous non-target species. Annals de la Societe Entomologique de France, 35: 502-508.

Su, T.; Mulla, M.S. And Zain, M.C.(2003): Laboratory and field evaluations of novaluron, a new insect growth regulator (IGR) against Culex mosquitoes. J. Ann. Mosq. Control Assoc., 19: 408-418.

(Fig.6)
Vasuki,V. (1992): Bioefficacy of an insect growth regulator, hexaflumuron (OMS3031, Xrd473), against three major vector mosquitoes. Tropical Biomedicine, 9:1-2, 19-

Vasuki, V. (1999): Influence of IGR treatment on oviposition of three species of vector mosquitoes as sublethal concentrations. South-East Asian J. Trop. Med. Puplic Health., 30:200-203.

Vasuki, V. and Rajavel, A. R. (1992): Influence of short time exposure to an insect growth regulator, hexaflumuron, on mortality and adult emergence of vector mosquitoes. Memorias do Instituto Oswaldo Cruz, 87 (2) 275- 283.

Vythilingam, I.; Luz, B.M.; Hanni, R.; Beng, T.S. and Huat, T.C. (2005): Laboratory and field evaluation of insect growth regulator, pyriproxyfen (Sumilarv) against Dengue vectors.J.Am.Mosq.Control Assoc., 21 (3):296-300. Willson, T.G. and Cryan, J.R. (1977): Lufenuron a chitin-synthesis inhibitor interrupts development of Drosophila melanogaster. J. Exp. Zool., 2278:37-44. 